\title{
The Effectiveness of Cyber Crime Handling by the Special Criminal Directorate North Maluku Polda
}

\author{
Irwan Ahdi; Syawal Abdulajid; Suwarti \\ Universitas Khairun Ternate, Indonesia \\ http://dx.doi.org/10.18415/ijmmu.v8i9.2905
}

\begin{abstract}
This study aims to analyze the indicators that affect the effectiveness of the handling of Cyber Crime by the Directorate of Crimes at the North Maluku Police. As well as to reveal the process of handling Cyber Crime by the Directorate of Crime and Crime of North Maluku Police. Currently there are technical obstacles that result in the lack of legal certainty related to the problem of Cyber Crime, including the lack of structural and channeled coordination, as well as an understanding of the application of Law Number 19 of 2016 concerning Amendments to Law Number 11 of 2008 About Information and Electronic Transactions. Thus, the indicators of success that can affect the effectiveness of handling Cyber Crime by the Directorate of Crimes at the North Maluku Police are the Legal Mastery of the Directorate of Crimes in North Maluku regarding the ITE Law, Appropriate Law Enforcement, Community Participation, and Adequate Facilities and Infrastructure. Efforts to Handle Cyber Crime by the Crimean Directorate of North Maluku Police are the control of investigators in the field of Technology by equipping and facilitating officers with special training related to Cyber Crime, as well as providing modern facilities in investigations/investigations. In addition, in dealing with cybercrimes, it is necessary to introduce the paradigm and construction of investigator thinking from formalistic to imaginative, progressive and prioritizes the benefit of the community.
\end{abstract}

Keywords: Handling Effectiveness; Cyber Crime

\section{Introduction}

Advances in science and technology are very influential on human life, this is marked by the development of information and communication technology. Currently, all activities of human life depend on the means of information technology, regardless of the age and background of each person's life. ${ }^{1}$

Advances in information technology that are so fast and rapid have a positive impact on the development of human life. Access to information and communication is currently using computers and internet networks, facilitating communication and information activities, this is evidence of the progress of the world of information and communication technology.

The development of information technology on the one hand contributes to the development of the quality of human life, but on the other hand it becomes an opportunity or space for committing a crime

${ }^{1}$ Barda Nawawi Arief, 2002, Kebijakan Hukum Pidana, PT. Citra Aditya Bakti, Bandung, hlm. 109. 
which is often called cyber crime. Cyber crime (English: cyber crime) is a term that refers to criminal activities in which a computer or computer network becomes a tool, target or place for crime. As already mentioned, this cyber crime act emerged along with the increasing intensity of digital, communication and information technology. The types of cyber crimes that occur in the world are data theft, Cyber Terrorism, Hacking, Carding, Defacing, Cyber Squatting, Cyber Typosquatting, Spreading Illegal content. ${ }^{2}$

With the development of cyber crime, law enforcement agencies, especially the National Police, must directly form a new task force that specifically handles cyber crime (Cyber Crime), by preparing all the equipment, both human resources (Human Resources), infrastructure, operational budget, and other equipment. This generally applies from the level of the National Police Headquarters to the ranks of the Regional Police, and Polres throughout Indonesia. The structure of the task force in charge of handling cyber crimes (Cyber Crime) at the Polda level is in the Special Criminal Directorate, Sub-Directorate V.

The establishment of a task force within a legal institution aims to optimize the handling of criminal acts that occur in accordance with the specifications of the violation or criminal act committed. Where the Directorate of Cyber Crime along with the structures formed to the lower units of the police is a form of the work of the State in enforcing the law. Supposedly the formation of a task force that is specifically in charge of Cyber Crime issues can make a major contribution in handling Cyber Crime crimes. ${ }^{3}$

All criminal acts that occur must be handled by the law thoroughly, where the Police institution, especially the Sub-Directorate V of the Criminal Investigation Directorate of the North Maluku Police in charge of Cyber Crime, can provide legal certainty to every person who has committed a crime in the field of Cyber Crime in the jurisdiction of the North Maluku Police. During 2020, 32 (thirty-two) cases of alleged Cyber Crime cases were reported, of which 7 (seven) cases have been fully declared by the research prosecutor (P21), 12 (twelve) cases are in the fingerprinting process, 5 (five) temporary cases in the investigation process, 4 (four) cases have arrived at the submission of case files to the Research Prosecutor in this case stage 1 (one), 4 (four) investigations have been terminated in this case SP3. In handling Cyber Crime by the Directorate of Criminal Investigation at the North Maluku Police, there are several difficult cases in the form of disclosing fake accounts used to commit crimes and online fraud, this requires hard work and a sharper deepening of the problem to be able to find a solution to the problem. ${ }^{4}$

Cyber Crime is a new thing with characteristics and colors that are different from other criminal acts in this case the incident is in the cyberspace area and is not limited to its territory depending on the perpetrator doing the act, this condition is very interesting and challenging in the world of investigation, this makes the author feel interested in conducting studies and research in order to determine the effectiveness of the handling of Cyber Crime by the Special Criminal Directorate of the North Maluku Police. From the description of the background above, several problems can be formulated what are the Indicators Affecting the Effectiveness of Handling Cyber Crime by the Special Directorate of the North Maluku Police?

Cybercrime is basically a crime that is concerned with information, the information system itself, and the communication system which is a means for delivering/exchanging that information to other parties (transmitter/orginator to recipient). According to Susanto, broadly speaking, cybercrime consists of two types, namely:

1. Crimes that use information technology as a facility. Examples of this first type of cybercrime activity are piracy (copyright or intellectual copyright and others), pornography, credit card fraud and theft (carding), fraud via e-mail, fraud and bank account break-ins, online gambling, terrorism, material internet related to zara (such as the spread of ethnic and racial or religious hatred), transactions and distribution of illegal drugs, sex transactions and others. ${ }^{5}$

\footnotetext{
${ }^{2}$ Hasibuan, Malayu S. P., 2005. Manajemen: Dasar, Pengertian dan Masalah, Edisi Revisi, PT. Bumi Aksara, Jakarta.

${ }^{3}$ Bernard, I, Chaster. 1992. Organisasi dan Manajemen Struktur, Prilaku dan Proses. Jakarta: Gramedia. Hal : 207.

${ }^{4}$ Dellyana,Shant.1988, Konsep Penegakan Hukum. Yogyakarta: Liberty, hlm. 33

${ }^{5}$ Sabartua Tambubolon, 2002. Domain Name: Nama Domain, Universitas Pelita Harapan, Jakarta Hal 64.
} 
2. Crimes that target information technology systems and facilities. This type of cybercrime does not use computers and the internet as media or targets for criminal acts, but makes them as targets. Examples of the types of crimes include illegally accessing a system (hacking), destroying internet sites and data servers (cracking) and defacting. ${ }^{28}$

Currently, cybercrime has become a global security issue in every country which indicates the need to secure access to internet information, especially those related to cybercrimes that can potentially threaten the stability of national security. Cybercrime is one of the new study materials in the scope of the study of international relations, especially in terms of upholding national interests related to maintaining and improving national security stability. In line with these security measures, efforts are also needed to optimize law enforcement against cybercrime more effectively.

\section{Theoretical Foundation}

\section{Effectiveness Theory}

Supriyono stated that effectiveness is the relationship between the output of a responsibility center and the targets that must be achieved, the greater the contribution of the output produced to the value of achieving the target, the more effective the unit can be. ${ }^{6}$ In line with the view related to the concept of output, another view states that effectiveness is the main element to achieve the goals or objectives that have been determined in every organization, activity or program. It is said to be effective if the goals or objectives are achieved as determined. ${ }^{7}$ This is also confirmed by another view which states that the notion of effectiveness can be understood as the level of success of a company to achieve its goals so that effectiveness is a measure of output.

The above understanding can be seen that the concept of effectiveness includes also in an organization. Related to this is the view that an organization is successful and may achieve its goals, largely determined by its managerial capabilities. On the other hand, if the managerial ability is low, the organization will fail to achieve its goals. Likewise, if an organization within a country achieves its goals, the country as a whole will gain prosperity. Good managerial ability is largely determined by performance management which is a measure of how efficient and effective the organization's management is, in this case the ability of members and organizational leaders to consider and achieve the right goals. ${ }^{8}$

\section{Research Methods}

This study uses empirical legal research, empirical legal research is carried out by examining the law in reality in the field. This type of research is often referred to as Socio Legal Research. ${ }^{9}$ In empirical legal research, what is studied initially is secondary data which is then continued with research on primary data in the field. ${ }^{10}$ While descriptive research is intended to provide data that is as accurate as possible about humans, circumstances or other symptoms. This study describes the effectiveness of handling Cyber Crime by the Dit Reskrimsus Polda Malut.

\footnotetext{
${ }^{6}$ Supriyono, 2000, Sistem Pengendalian Manajemen, Universitas Diponegoro, Semarang, hlm. 29.

${ }^{7}$ Iga Rosalina, Efektivitas Program Nasional Pemberdayaan Masyarakat Mandiri Perkotaan Pada Kelompok Pinjaman Bergulir Di Desa Mantren Kec Karangrejo Kabupaten Madetaan, Jurnal Efektivitas Pemberdayaan Masyarakat, Vol. 01 No 01 (Februari 2012), h.3.

${ }^{8}$ Wibowo, Manajemen Kinerja, Rajawali Pers, Depok, Cet. IV, 2014, h. 88-89.

${ }^{9}$ Bambang Sunggono, 2009, Metode Penelitian Hukum, Jakarta, Raja Grafindo Persada, hlm. 42.

${ }^{10}$ Suyanto dan Sutinah. 2005. Metode Penelitian Sosial : Berbagai Alternatif Pendekatan. Hlm. 55.
} 


\section{Research Results and Discussion}

\section{Success Indicators Affecting the Effectiveness of Handling Cyber Crime by the Directorate of Crime and Crime of the North Maluku Police}

The current reality which is rooted in the concept of proving that society in general cannot be separated from technological advances which underlies the ease of getting information quickly. So it is necessary to enact a law to regulate this matter. The existence of the law, in principle, is a regulation of the attitude (behavior) of a person and the community who have violated it are subject to sanctions by the state. Even though the cyber world is a virtual world, the law is still needed to regulate people's attitudes. ${ }^{11}$

In an opinion according to Wolf Middendorf as quoted by Barda Nawawi Arif, ${ }^{12}$ it is said that law enforcement will run effectively if three interrelated factors are met, namely: (1) the existence of good legislation; (2) quick and certain enforcement; and (3) punishment that is appropriate or moderate and uniform (moderate and uniform sentencing). Law enforcement is considered to be effective if it fulfills three interrelated factors, namely: good laws, fast and definite implementation, and proper law enforcement according to the level of guilt of the perpetrators of criminal acts.

At least for two reasons. First, people who exist in the virtual world are people who come from the real world; The community has values and interests both individually and collectively that must be protected. Second, even though they occur in the virtual world, transactions carried out by the public have an impact in the real world, both economically and non-economically. Because Cybercrime is one of the dark sides of technological progress that has a very broad negative impact on all areas of modern life today. With these technological advances, some people very easily enter the scope of crime just by relying on their ability to drive technological systems.

In Law Number 11 of 2008 concerning Information and Electronic Transactions (UU ITE) which is a formal form of a system with the aim of providing a sense of security, justice, and legal certainty for users and providers of Information Technology. The anxiety of users and organizers is why a law is believed to be capable of being an information technology control system. In a law, it must have material coverage that explains the extent of the rules in it. This of course needs to be explained and needs to be known about what materials are covered in the ITE Law which is the first cyberlaw in Indonesia that specifically regulates information and technology transactions.

The material of the ITE Law can be grouped into two major parts, namely the regulation of information and electronic transactions, and the regulation of prohibited acts (cyber crime). Regulatory effectiveness is the discussion of laws based on the positive norms contained in them, while objective effectiveness is the discussion of the question of whether a law can achieve the desired goals with the formation of a law.

The distinction between the effectiveness of regulations and the effectiveness of objectives needs to be made because not every effective regulation can lead to the purpose of making a regulation. The normative formulation is an analytical formulation, and the analytical formulation cannot reveal all sociological factors, because sociological factors often appear after the enactment of a law. ${ }^{13}$ Thus, the control of the Law of the Police, especially the Directorate of Crimes at the North Maluku Police regarding the ITE Law can be an indicator of success that affects the effectiveness of handling cyber crimes by the Directorate of Crimes at the North Maluku Police.

Crime is a portrait of the concrete reality of the development of community life which directly or indirectly creates a vulnerability that has the potential to give birth to individuals with deviant behavior. Within society there is a struggle for interests that are not always fulfilled in the right way, meaning that

\footnotetext{
${ }^{11}$ Adami Chazawi. 2005. Tindak Pidana Mengenai Kesopanan,Rajagrafindo Persada, Jakarta.

12 Barda Nawawi Arif, Kebijakan Legislatif dalam Penanggulangan Kejahatan dengan Pidana Penjara, Cetakan Ketiga, Badan Penerbit UNDIP, Semarang, 2000, hlm. 83

${ }^{13}$ Radita Setiawan, 2013, Efektivitas Undang-Undang Informasi Dan Transaksi Elektronik di Indonesia Dalam Aspek Hukum Pidana, Recidive Vol 2 No 2 Mei-Agustus, hlm. 143
} 
there are ways that are not right and violate the law by a person or group of people to fulfill their interests.

As a type of crime that endangers the lives of individuals, society and the state. This type of crime (cyber crime) is not appropriate to be called a "crime without victims", but can be categorized as a crime that can cause multiple victims, both privately and publicly. Private rights can be threatened, disturbed, even lost/damaged due to the actions of a handful of people or several people who take advantage of the advantages of their knowledge and technology with a modus operandi that is classified as cyber crime.

In relation to criminal acts of electronic transaction information, law enforcement cannot be separated from the role and commitment of law enforcers, namely: investigators,

The legal function, mentality or personality of law enforcement officers play an important role. If the regulations are good, but the quality of the officers is not good, there is a problem. Therefore, one of the keys to success in law enforcement is the mentality or personality of law enforcement.

\section{Supporting Facilities or Facilities}

Indicators of supporting facilities or facilities include software and hardware. One example of software is education. The education received by the police today tends to things that are practically conventional, so that in many cases the police experience obstacles in their goals, including knowledge about computer crimes, which in special crimes have so far been given authority to the prosecutor. technical juridical police are considered incapable and not ready. Although it is also realized that the tasks that must be carried out by the police are very broad and many.

\section{Community Participation}

Law enforcement comes from the community and aims to achieve peace in society. Every member of the community or group mostly has legal awareness. The problem that arises is the level of legal compliance, namely high, moderate, or less legal compliance. The degree of community legal compliance with the law is one indicator of the functioning of the law concerned.

Law No. 2 of 2002 concerning the National Police of the Republic of Indonesia in Article 1 paragraph (1) it is explained that the Police are all matters relating to the functions and institutions of the police in accordance with statutory regulations. The term police in this law contains two meanings, namely the function of the police and the police institution. In Article 2 of Law N0.2 of 2002 concerning the National Police of the Republic of Indonesia, the function of the police is as one of the functions of the state government in the field of maintaining security and public order, law enforcement, protector, protector and service to the community. Meanwhile, the police agency is a government organ that is designated as an institution and is given the authority to carry out its 17 functions based on statutory regulations. ${ }^{14}$

\section{Process of Investigation and Investigation in Handling Cyber Crime by the Directorate of Criminal Investigation at the North Maluku Police}

In the process of investigating cyber crime there are several stages where the stages in this investigation are the earliest stages starting from the entry of a case or the reporting of a crime/crime to the investigator to the stage of the investigation process and or the results of the investigation, so that it is easier to understand the author explains in the form of images/graphics according to the stages in the investigation process. The description of the investigation process on cyber crime in the Cyber Crime Unit of the Crime Investigation Unit of the North Maluku Police is as follows:

\footnotetext{
${ }^{14}$ Sadjijono, 2008, Ulasantentang Undang-Undang N0.2 Tahun 2002 Tentang Kepolisian Negara Republik Indonesia Pasal 2 Tentang Fungsi Kepolisian, Gramedia Pusaka Utama, Jakarta. Hlm. 52-53
} 


\section{Figure 3.1}

\section{The Investigation Process at the Cyber Crime Unit DITRESKRIMSUS POLDA MALUT}

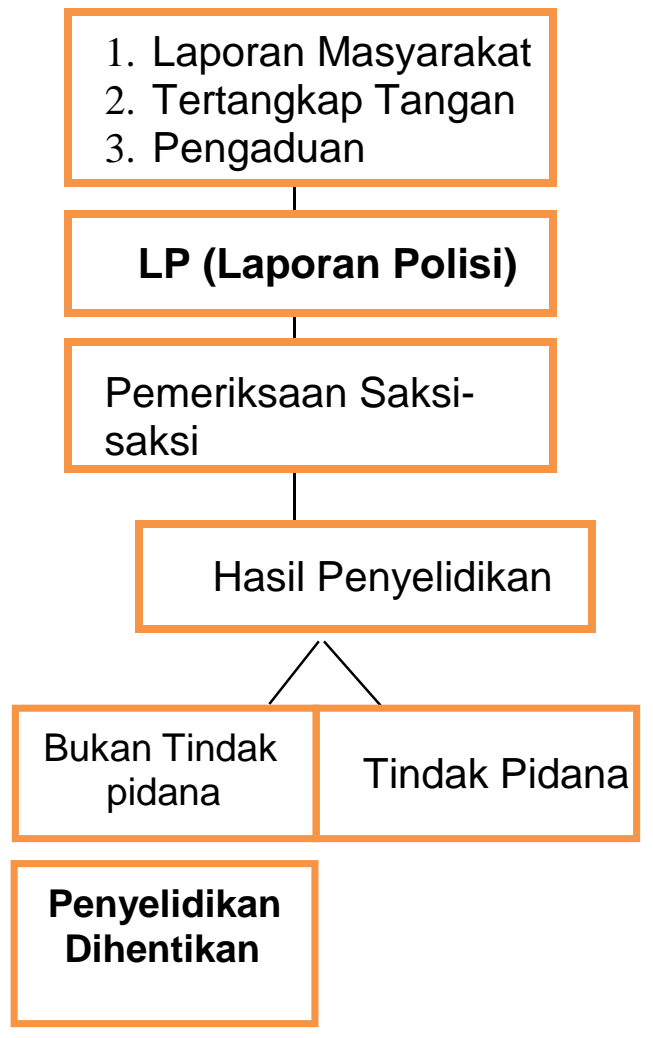

Hasil Penyelidikan/ Upaya Paksa

1. Pemanggilan

2. Penggeledahan

3. Penyitaan

4. Penangkapan

5. Penahanan

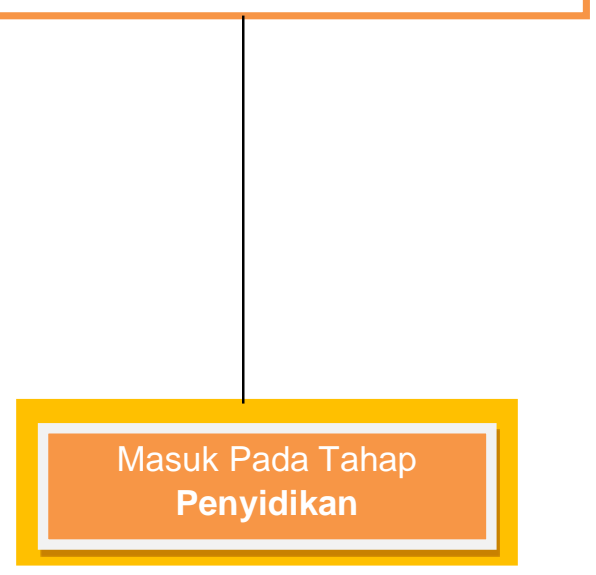

(source: DITRESKRIMSUS Cyber Crime Unit POLDA MALUT)

Based on the picture above regarding the investigation process on cyber crime, the stages start from:

a. Receive a report or complaint from someone regarding the existence of a criminal act in the field of Information Technology and Electronic Transactions;

b. Summon any person or other party to be heard and examined as a suspect or witness in connection with an alleged criminal act in the field of Information Technology and Electronic Transactions;

c. Conduct an examination of the veracity of reports or information regarding criminal acts in the field of Information Technology and Electronic Transactions;

At this stage of the investigation, it is actually only up to the stage of the results of the investigation which is an investigation in a case where it is proven that the case is a criminal act or not, but in this case the author makes summons, searches, confiscations, arrests, and detentions, this is if at a In cases of cybercrime crime, OTT (hand arrest operations) actions are carried out by investigators and or in the case of forced efforts, at the investigation stage, summons, searches, confiscations, arrests, and detentions have been carried out, and so on, in this case it is adjusted to the conditions in the handling or prosecution in a cyber crime case, even though we know that the investigation is part of a series in the investigation process.

In the process of investigating cyber crime there are several stages where the stages in this investigation are the stages carried out after the investigation stage is carried out by the investigator, the investigation process is carried out starting from the issuance of the SPDP (order for the start of the 
investigation) to the stage of submitting the case file to the prosecutor (Prosecutor). public prosecutor) and up to the stage of prosecution carried out by the Public Prosecutor. Thus, regarding the investigation process on cyber crime, the stages start from:

a. The issuance of the SPDP marks the start of the investigator's task to collect sufficient preliminary evidence, namely at least two pieces of evidence to establish a person as a suspect or to stop him later.

b. Conduct investigations into existing evidence and seek or collect other evidence to strengthen the evidence in the trial and or not be wrong in taking action on a cyber crime case.

c. Summoning witnesses from victims to explore further cases that actually occurred based on witnesses from victims to be used as additional evidence in a cyber crime case.

d. Summoning of witnesses from the reported to explore further the case based on the statements of witnesses from the reported to be used as additional evidence and consideration in the investigation of a cyber crime case.

e. The case title is a PPNS activity to describe cases and actions that will be, are being, and have been investigated, in order to obtain conclusions.

f. Determination of the suspect, namely raising the status of the reported party to be a suspect or a person who because of his actions or circumstances, based on preliminary evidence, should be suspected as a perpetrator of a cyber crime.

At the stage of investigating cyber crime, when compared to conventional criminal acts, it can be said that cyber crime is more complicated, judging from the perpetrators and victims, they are also often in different cities and even different countries, and the evidence is not as easy as the crime in In general, where the evidence in cyber crime is also if it is slow in reporting then the perpetrators can easily remove their digital traces, and furthermore regarding the summoning of witnesses is also very complicated in cyber crime because it is often constrained by the distance that is not close to the victim and perpetrators need more time and more budget in conducting investigations in this crime. ${ }^{15}$

\section{Conclusions and Suggestions}

The handling of cybercrime crimes carried out by the Directorate of Crime and Crime of the North Maluku Regional Police currently has technical obstacles that result in the lack of legal certainty related to Cyber Crime crimes, including the lack of structural and channeled coordination, as well as understanding of the application of the Act. Number 19 of 2016 concerning Amendments to Law Number 11 of 2008 concerning Information and Electronic Transactions from both the Ternate City Police Agency, especially the Directorate of Crime and Crime of the North Maluku Police and the Kominfo agency. Thus, the indicators of success that can affect the effectiveness of handling Cyber Crime by the Directorate of Crimes at the North Maluku Police are the Legal Mastery of the Directorate of Crimes in North Maluku regarding the ITE Law, Appropriate Law Enforcement, Community Participation, and Adequate Facilities and Infrastructure.

\section{Bibliography}

\section{Book}

Ahmad Ali. 2009. Revealing Legal Theory and Judicial Prudence: Including the Interpretation of Laws (Legisprudence). Jakarta: Prenada Media Group.

${ }^{15}$ IBK. Bayangkara, Audit Manajemen (Prosedur dan Implementasi), Salemba Empat, Jakarta, Cet. II, 2008, h. 14. 
Adam Chazawi. 2005. Crimes Regarding Politeness, Rajagrafindo Persada, Jakarta. , 2007, Criminal Law Study II, Raja Grafindo Persada, Jakarta.

Agus Raharjo. 2002. Cybercrime Understanding and Prevention of Technological Crime, Citra Aditya Bakti, Bandung.

Amir Ilyas, 2012, Principles of Criminal Law, Rangkang Education Yogyakarta \& PuKAP-Indonesia, Yogyakarta.

Anthony, R.N and Vijay Govindarajan. (2005). Management control system: Management control system. Edition 11. Jakarta: Salemba Empat.

Apeldoorn. L J. van, 1982, Introduction to Law, Jakarta, Pradnya Paramita.

Bambang Sunggono, 2009, Legal Research Methods, Jakarta, Raja Grafindo Persada.

Barda Nawawi Arief, 1996. Legislative Policy in Combating Crime with Imprisonment. Diponegoro University Publishing Agency, Semarang. ,2002, Criminal Law Policy, PT. Citra Aditya Bakti, Bandung.

Bernard, I, Chaster. 1992. Organizational and Management Structure, Behavior and Process. Jakarta: Gramedia.

C.S.T. Kansil and Christine S.T Kansil, 2004, Principles of Criminal Law, Pradnya Paramita, Jakarta.

Dellyana, Shant. 1988, The Concept of Law Enforcement. Yogyakarta: Liberty .

Deris Setiawan. 2005. Computer Security System, PT Elex Media Komputindo, Jakarta.

Dirdjosisworo, Soedjono, Introduction to Legal Studies, Jakarta, Fajar, 1983.

Eva Achjani zulfa, 2008, When the Age Left the Law, Citra Aditya Bakti. Bandung.

Hans Kelsen, 2007, General Theory of Law and State (Translation edition by Raisul Muttaqien), Bandung, Nusa Media and Nuansa.

Hasibuan, Malayu S. P., 2005. Management: Basics, Understanding and Problems, Revised Edition, PT. Earth Literacy, Jakarta.

Heru Soepraptomo. 2000. The role of computers in industry and its influence on the field of law, Alumni. Bandung.

Hironymus Jati, The Poor Make Money Through Gambling, Rajawali Pers. Jakarta.

Jan Remmelink, 2003, Criminal Law "Comments on the Most Important Articles of the Dutch Criminal Code and their Equivalents in the Indonesian Criminal Code, Gramedia Pustaka Utama, Jakarta.

Sabartua Tambubolon, 2002. Domain Name: Domain Name, Pelita Harapan University, Jakarta.

Soerjono soekanto, 2007, Factors Affecting Law Enforcement, Jakarta, Rajawali Pers.

Suyanto and Sutinah. 2005, Social Research Methods: various alternative approaches.

Zainal Abidin and Andi Hamzah. 2010, Indonesian Criminal Law. Jakarta: Yarsif Watampone.

\section{Laws and Regulations}

Criminal Code (KUHP)

Law Number 8 of 1981 concerning Criminal Procedure Code (KUHAP)

Law No. 2 of 2002 concerning the Indonesian National Police

RI Law No. 19 of 2016 concerning Amendments to Law Number 11 of 2008 concerning Information and Electronic Transactions. 
National Police Chief Regulation No. 6 of 2019 concerning Police Investigation Management.

\section{Website}

http://itsmeryd.com/2012/12/cyber-crime-diIndonesia.html accessed on March 25, 2021

\section{Copyrights}

Copyright for this article is retained by the author(s), with first publication rights granted to the journal.

This is an open-access article distributed under the terms and conditions of the Creative Commons Attribution license (http://creativecommons.org/licenses/by/4.0/). 